\title{
INTRAHEPATIC VASCULAR AND BILE-DUCT SYSTEMS AS RELATED TO OPERATIVE TREATMENT OF BILE-DUCT ATRESIA*
}

\author{
BY \\ WOLFGANG HASSE \\ From the Department of Surgery, Free University, Westend Hospital, West-Berlin, Germany
}

More than $80 \%$ of infants suffering from congenital biliary atresia are found to be inoperable at laparotomy (Grewe and Arius, 1961 ; Grewe and Pape, 1962; Grob, 1957; Gross, 1953; Hasse, 1963, 1964a, b; Hecker and Daum, 1964; Ladd, 1935; Rehbein and Neumann, 1957). The attempts to relieve the bile stasis by hepatogastrostomy (Gohrbandt, 1957), or cholangiojejunostomy (Longmire and Sanford, 1948, 1949) have been unsuccessful, nor has Sterling's (1961) method of establishing internal hepatic fistulae by using artificial bile-duct reduced the mortality rate.

In order to find a basis for treatment in inoperable * A paper read at a meeting of the British Association of Paediatric
Surgeons in Rotterdam, September 1964 . extrahepatic biliary atresia, the intrahepatic vascular and bile-duct systems of 40 normal livers of newborns and infants have been studied. These studies began in May 1962 independently of the work of Healey and Sterling published in December 1963 in their monograph: 'Segmental Anatomy of the Newborn Liver'.

The livers were removed from the body 10 to 48 hours after death and the vascular and bile-duct systems were injected with 'plastoid' by Schummer's (1951) method. In addition, the intrahepatic bileducts were studied (a) radiographically by injecting barium, and (b) by the use of ${ }^{131}$ I-labelled hippuric acid solution.

As in adults (Rex, 1888; Cantlie, 1898; Healey and Schroy, 1953; Hjortsjö, 1948; Couinaud, 1954;

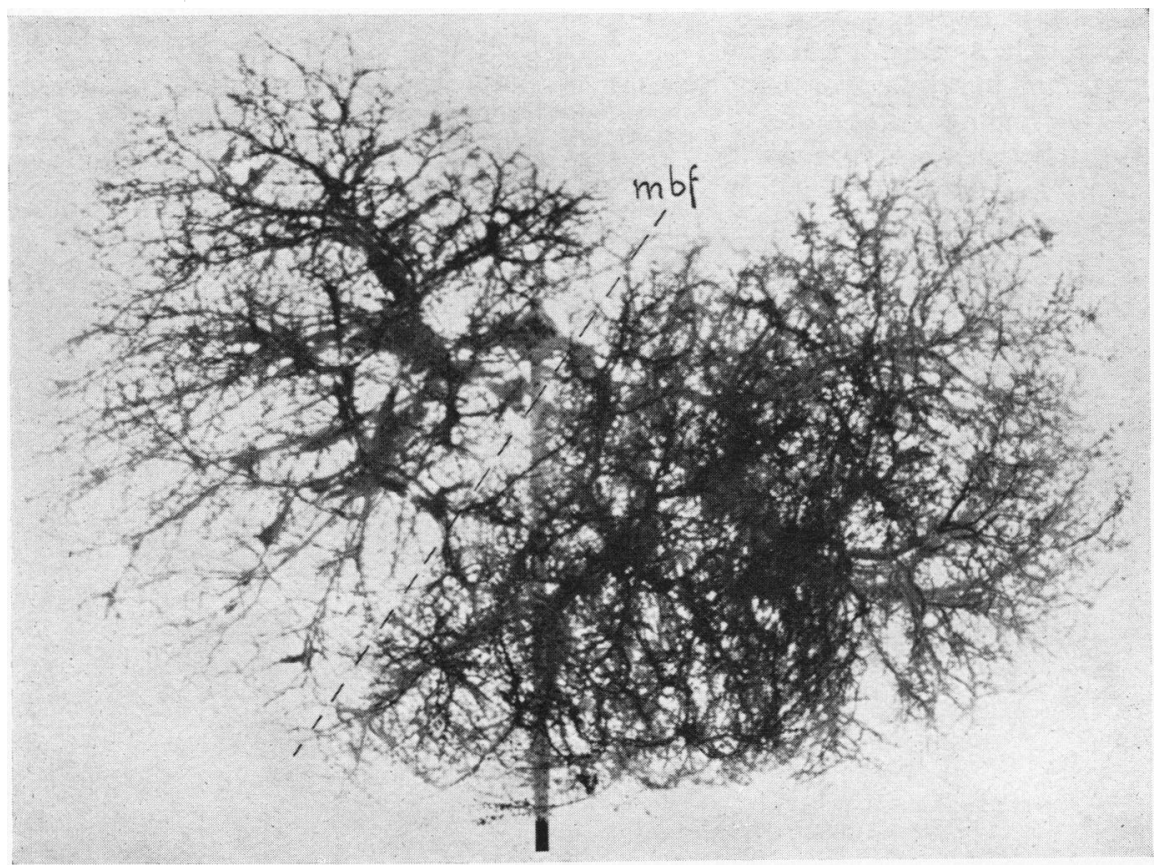

FIG. 1.-A liver cast of a 1-day-old infant, anterior view. Hepatic artery injected with 'plastoid' (mbf $=$ main boundary fissure). 
Stucke, 1959; Reifferscheid, 1957; Nettelblad, 1954; Røjel, 1958), the liver of the newborn infant is divided into a functional right and left lobe. Fig. 1 demonstrates the branches of the hepatic artery. The main boundary fissure is to be seen exactly between the two functional lobes. This fissure continues as a plane of connective tissue from the gall-bladder to the inferior vena cava.

The isolated injected right hepatic artery (Fig. 2) reveals the main boundary line very distinctly. No anastomoses are seen between the two functional lobes.

The intrahepatic branches of the portal vein demonstrate precisely the segments of the newborn and infant liver (Fig. 3).

To the right branch of the portal vein belong: (1) the right portion of the caudate lobe; (2) the processus caudatus; (3) a ventral segment; and (4) a dorsal segment.

The left branch of the portal vein provides: (1) the left portion of the caudate lobe; (2) the quadrate lobe;

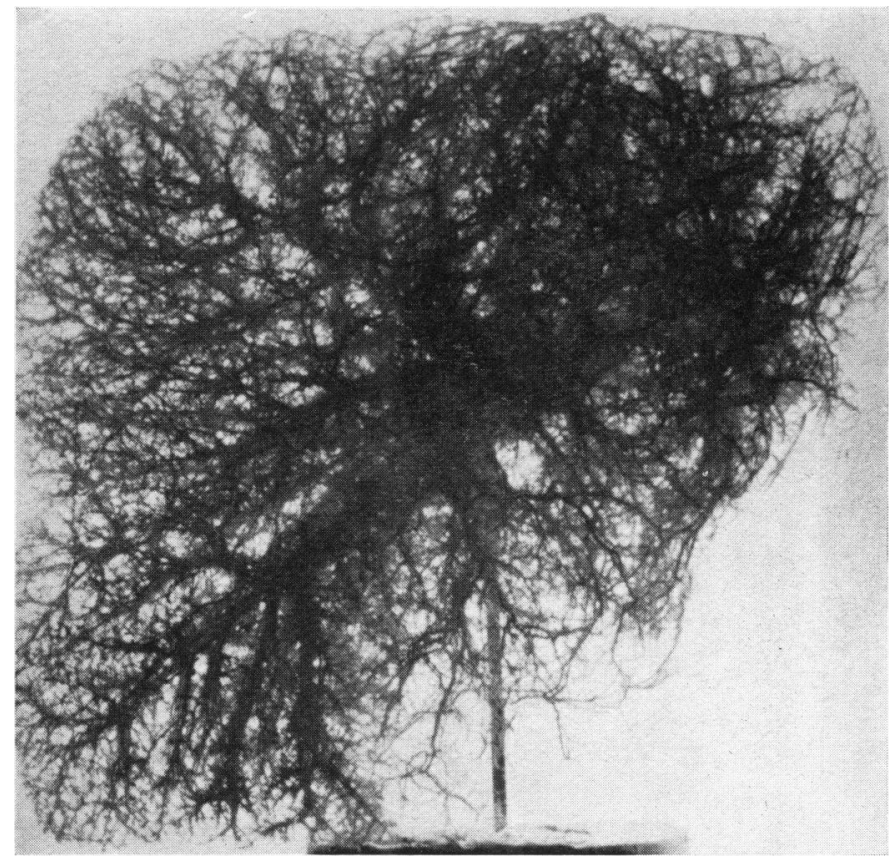
(3) a ventro-lateral segment; and (4) a dorso-lateral segment.

Fig. 2--Isolated, injected right hepatic artery of a 4-day-old infant, anterior view. The absence of anastomoses between the two functional lobes has prevented any of the medium passing into the left functional lobe.

Fig. 3.-Segmental branches of the portal vein of a 3-day-old infant, anterior view. The ductus venosus and umbilical vein were patent.

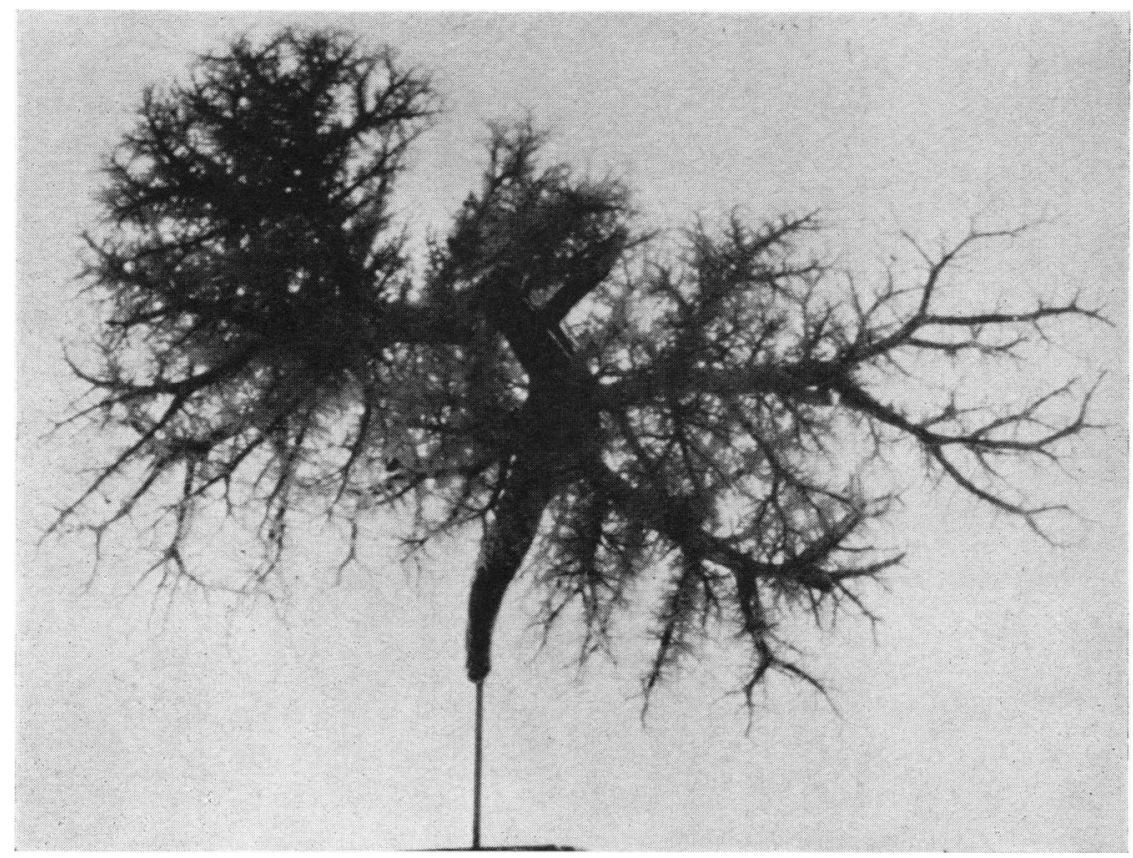




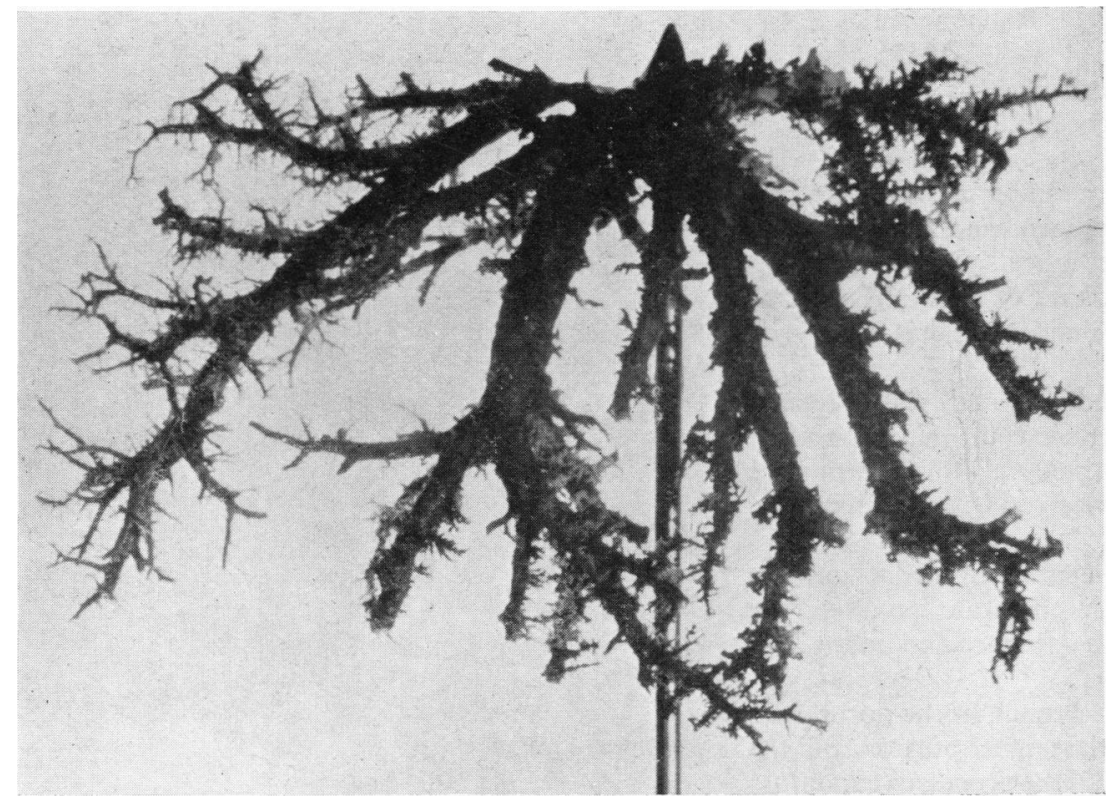

FIG. 4.-Hepatic veins of a 2-day-old infant, anterior view.

The hepatic vein receives a supply by a right, branches have a diameter of only $1 \mathrm{~mm}$. Intramiddle, and left hepatic vein (Fig. 4).

The intrahepatic bile-duct system of the infant is extremely delicate, as is shown in Fig. 5. Even the intrahepatic cholangiogram illustrates the fineness of the bile-duct system (Fig. 6). The segmental hepatic anastomoses of the bile-ducts between the two functional lobes are never seen, though Hartmann (1960) described such anastomoses in the adult liver.

Neither by injection of barium into the left

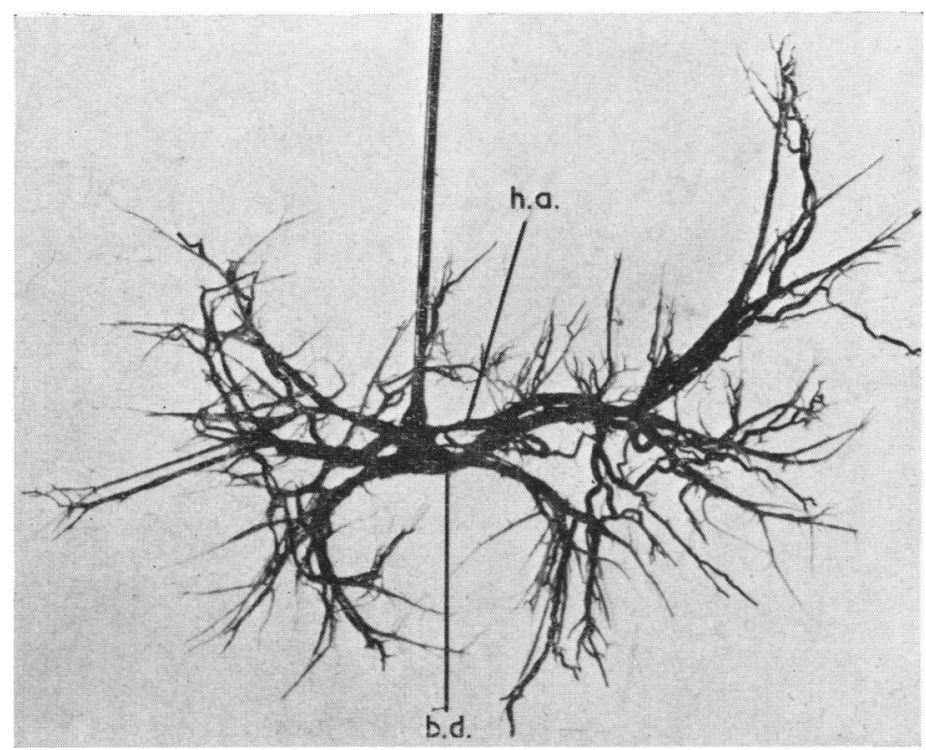

Fig. 5.-Segmental branches of the hepatic artery (h.a.) and bile-ducts (b.d.) of a 6-month-old infant, anterior view. 


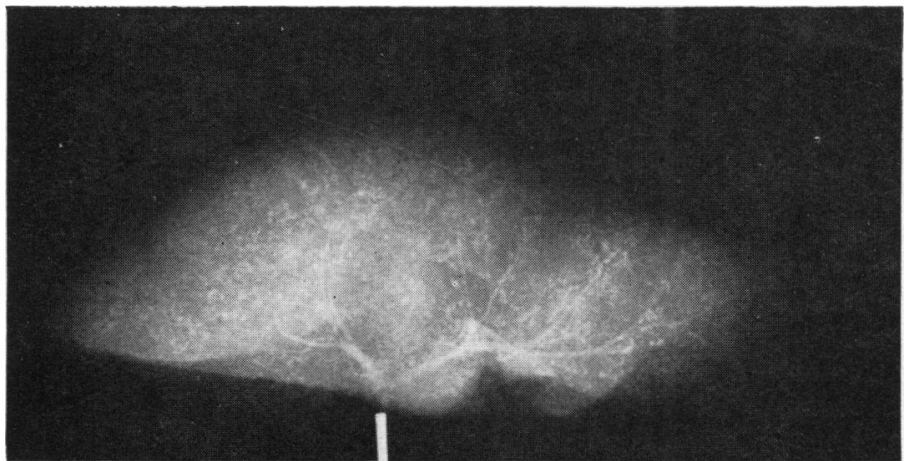

FIG. 6.-Intrahepatic cholangiogram of a 3-day-old infant. Caudo-cranial x-ray examination.

hepatic duct (Fig. 7), nor by injection of ${ }^{131}$ I-labelled hippuric acid solution into the right hepatic duct (Fig. 8), could the agents be detected in the contralateral lobes.

On the basis of these studies, the liver of the newborn infant can be divided into 6 segments (see Fig. 10): (1) caudate lobe with processus caudatus; (2) a right ventral segment; (3) a right dorsal segment; (4) quadrate lobe; (5) a left ventrolateral segment; and (6) a left dorso-lateral segment.

As far as surgical treatment of the so-called inoperable extrahepatic biliary atresia is concerned, we concluded the following.

(a) To achieve a sufficient bile flow and a functioning anastomosis between the intrahepatic bile-ducts and the intestinal tract, the largest possible bile-ducts have to be identified. Only the hepatic ducts are sufficient in this sense, the peripheral segment branches being too small.

(b) These hepatic ducts may end blindly or with a confluence within the liver, as is shown in Fig. 9.
This schematic drawing demonstrates a personal classification of the 10 possible types of biliary atresia. To identify these intrahepatic ducts in types 7 or 8 , it seems to be necessary to resect the central portion of the quadrate lobe.

(c) The peripheral wedge excision of the quadrate lobe according to Nixon (1964) and Grewe (1964) seems not to be the treatment of choice, because the liver hilum, where the intrahepatic hepatic ducts should be found, cannot be opened widely enough.

(d) With type 8 biliary atresia, both functional lobes of the liver could be drained of bile only by resection of the central portion of the quadrate lobe.

(e) The procedures of hepatogastrostomy (Gohrbandt, 1957) and cholangiojejunostomy (Longmire and Sanford, 1948, 1949) must be inadequate on the basis of the present findings: whether or not a normal intrahepatic bile-duct system has developed must be unknown, and in the case of an atresia type 8 the biliary system of the right functional lobe would not be drained, because

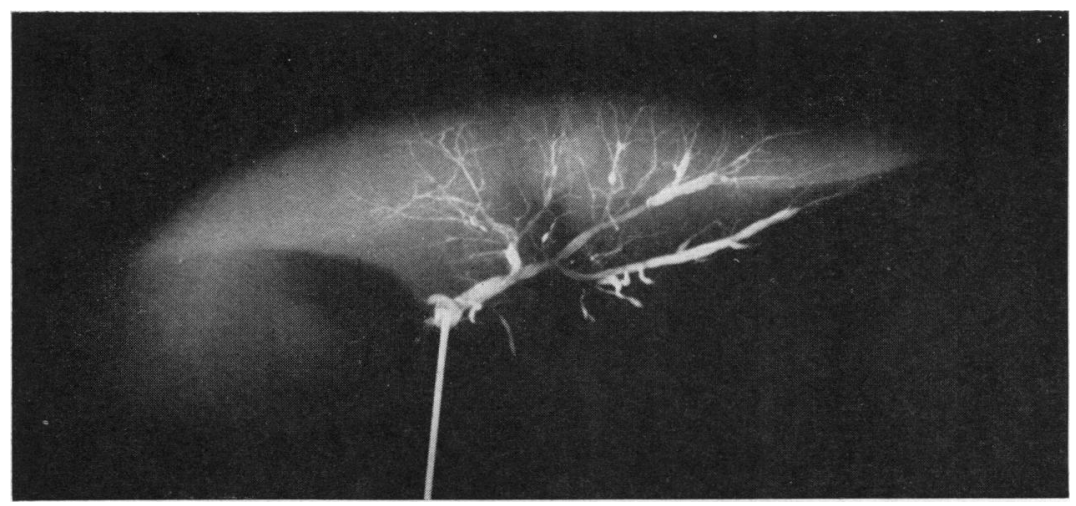

Fig. 7.-Isolated, injected left hepatic duct with barium. No anastomoses between the two functional lobes. 


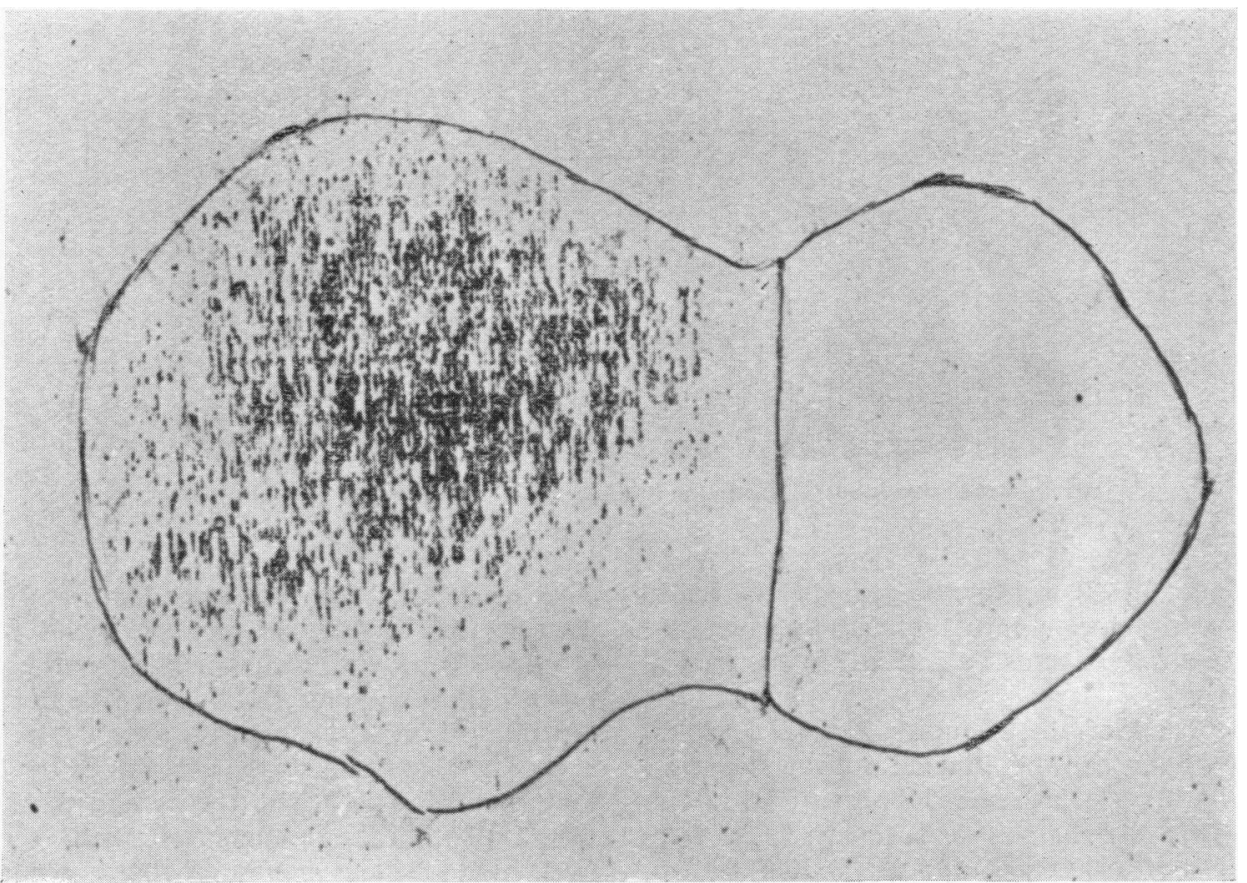

FIG. 8.-Scintigraph of a liver cast of a 6-cay-old infant. Right hepatic duct injected with ${ }^{131}$ I labelled hippuric acid solution. Absence? of anastcmoses to the left functional lobe.

intrahepatic anastomoses of the bile-ducts are absent.

(f) Bile-duct atresias of type 9 and 10 cannot be corrected by resection of the quadrate lobe.
With these conclusions in mind, a resection of the central portion of the quadrate lobe was carried out in 3 infants suffering from an inoperable bile-duct atresia. The topographical relation of the quadrate
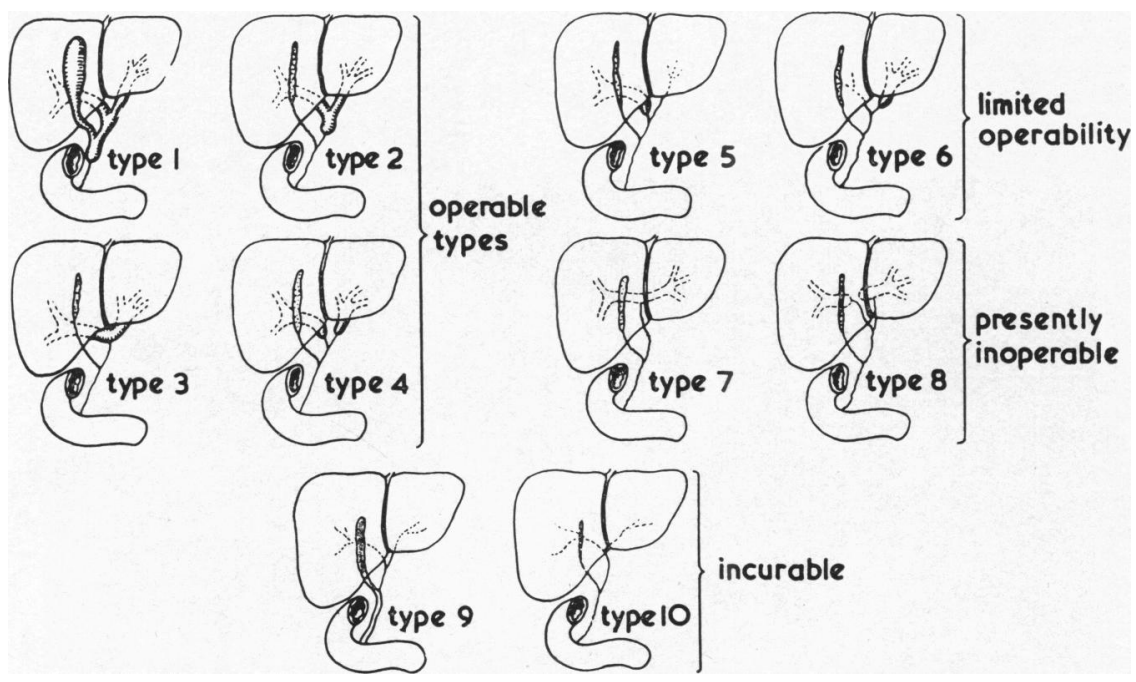

FIG. 9.-The 10 possible types of biliary atresia.

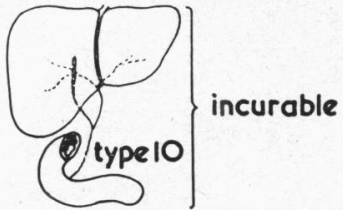




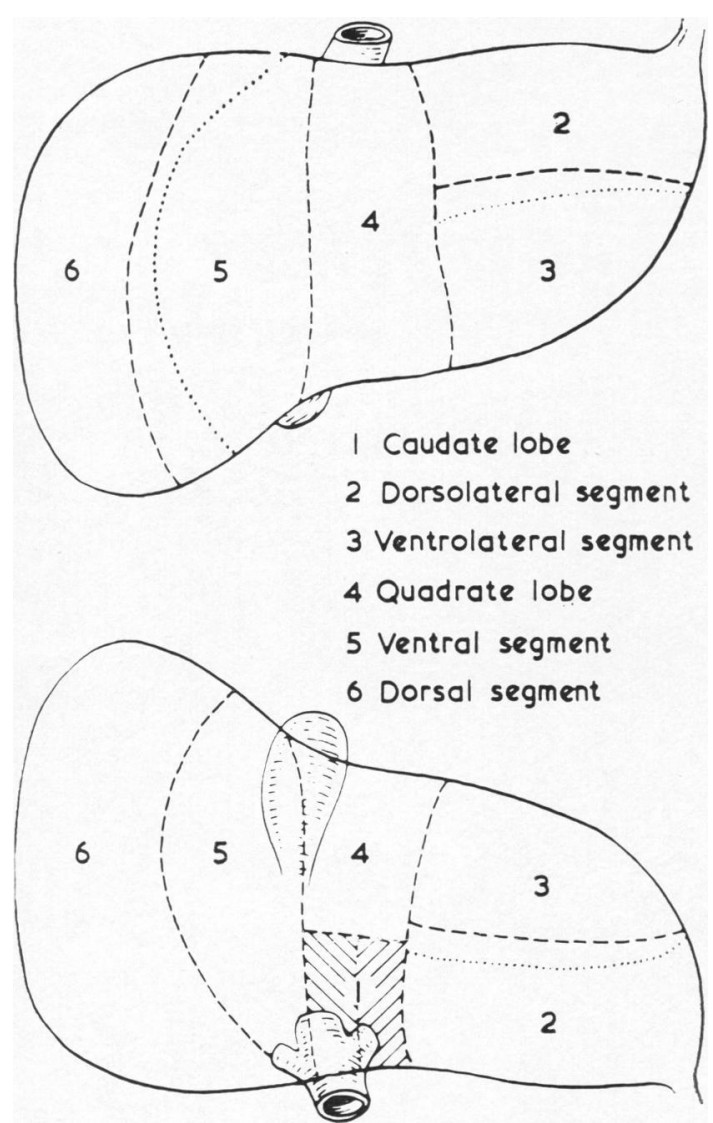

lobe is shown in Fig. 11. In no cases could blindlyending hepatic ducts within the liver be found. In one an atresia of type 9 was seen and in the other two a type 10 . The two cases of type 10 atresia were confirmed by necropsy; the other child is still alive.

\section{Summary}

The normal anatomy of the vascular and bile-duct systems of the liver in the newborn infant has been studied.

The biliary systems of the right and left functional lobes do not anastomose with one another.

This fact provides a basis for the surgical treatment of those cases of extrahepatic biliary atresia that are generally considered as inoperable.

\section{REFERENCES}

Cantlie, J. (1898). On a new arrangement of the right and left lobes of the liver. J. Anat. Physiol, , 32, iv.

Couinaud, C. (1954). Étude des voies biliaires intra-hépatiques. J. Chir. (Paris), 70, 310.

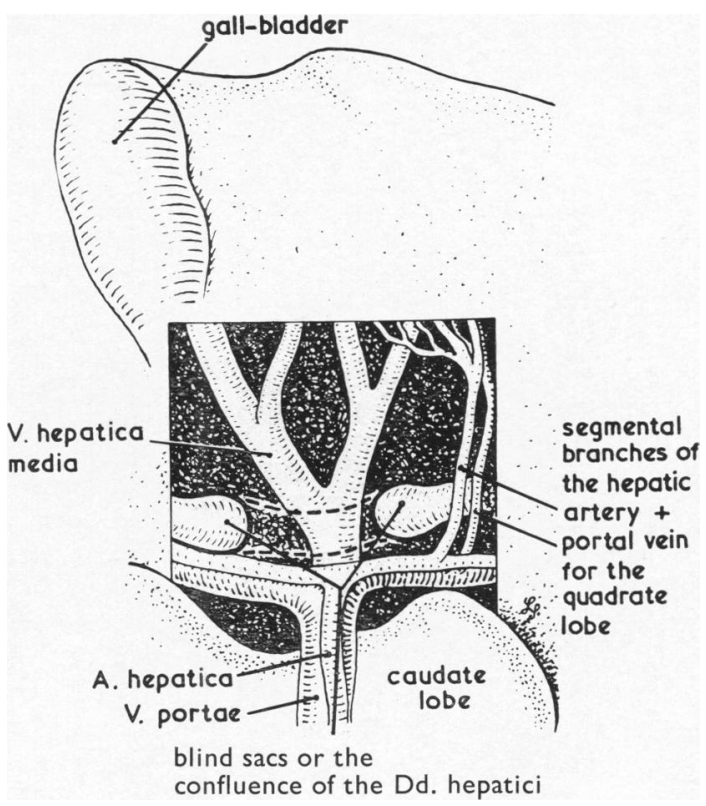

FIG. 11.-Schematic drawing of the quadrate lobe after resection of the central portion.

Fig. 10 (left).-The six segments of the newborn and infant liver.

Gohrbandt, E. (1957). Hepato-gastrostomie. Zbl. Chir., 82, 641. Grewe, H. E. (1964). Zur operativen Behandlung von Gallengangsatresien. ibid., 89, 145.

- - , and Arius, G. (1961). In Die chir. Behandlung der angeborenen Fehlbildungen, ed. K. Kremer. Thieme, Stuttgart.

- , and Pape, M. (1962). Zur Diagnostik und Therapie des Verschlussikterus im Säuglingsalter. Mschr. Kinderheilk., 110, 381.

Grob, M. (1957). Lehrbuch der Kinderchirurgie. Georg Thieme, Stuttgart,

Gross, R. E. (1953). The Surgery of Infancy and Childhood. Saunders, Philadelphia and London.

Hartmann, H. (1960). Beitrag zur Chirurgie der Gallenwegsverschlüsse. Langenbecks Arch. klin. Chir., 296, 1.

Hasse, W. (1963). Inoperable Gallengangsat resie und Relaparotomie. Chirurg, 34, 254

- - (1964a). Gefässtopographische Studien als Grundlage zur Chirurgie der Säuglingsleber. Kinderchir. Symposion Wien. (1964b). Gefässtopographische Studien an der Säuglingsleber als Grundlage für die Chirurgie der sog. inoperablen extra hepatischen Gallengangsatresie. Lagenbecks Arch. klin. Chir., 308, 766.

Healey, J. E., and Schroy, P. C. (1953). Anatomy of the biliary ducts within the human liver. Arch. Surg., 66, 599.

- and Sterling, J. A. (1963). Segmental anatomy of the newborn liver. Ann. N. Y. Acad. Sci., 111, 25.

Hecker, W. Ch., and Daum, R. (1964). Beitrag zum Problem der sog. inoperablen Gallengangsatresie. $\mathrm{Zbl}$. Chir., 89, 150. 
Hjortsjö, C. H. J. (1948). Die Anatomie der intrahepatischen Gallengänge beim Menschen, mittels Röntgen- und Injektionstechnik studiert, nebst Beiträgen zur Kenntnis der inneren Lebertopographie. Gleerup, Lund.

Ladd, W. E. (1935). Congenital obstruction of the bile ducts. Ann. Surg., 102, 742.

Longmire, W. P., Jr., and Sanford, M. C. (1948). Intrahepatic cholangiojejunostomy with partial hepatectomy for biliary obstruction. Surgery, 24, 264.

—_ - (1949). Intrahepatic cholangiojejunostomy for biliary obstruction-further studies. Ann. Surg., 130, 455.

Nettelblad, S. C. (1954). Die Lobierung und innere Topographie der Säugerleber. Acta. anat. (Basel), Supp. 20, 21.
Nixon, H. H. (1964), Leberchirurgie im Kindesalter. Kinderchir. Symposion Vienna,

Rehbein F., and Neumann, G. (1957). Angeborene Gallengangsatresie. Kinderärztl. Prax., 25, 78.

Reifferscheid, M. (1957). Chirurgie der Leber. Thieme, Stuttgart.

Rex, H. (1888). Beiträge zur Morphologie der Säugerleber. Morph. Jb., 14, 517.

Røjel, K. (1958). Surgical anatomy of the liver. Acta chir. scand., $114,277$.

Schummer, A. (1951). Vereinfachtes Plastoid-Korrosionsverfahren. Anat. Anz., 98, 288.

Sterling, J. A. (1961). Artificial bile ducts in the management of congenital biliary atresia. J. int. Coll. Surg., 36, 293.

Stucke, K. (1959). Leberchirurgie. Springer, Berlin. 